\title{
THE CHALLENGES OF PARENTAL INVOLVEMENT IN EARLY CHILDHOOD INCLUSION
}

\author{
Lily Eka Sari \\ Faculty of Teacher Education, Petra Christian University \\ lilyesari@petra.ac.id
}

\begin{abstract}
Abstrak
Pendidikan inklusif di usia dini mengharuskan adanya kolaborasi orang tua murid dan guru. Penelitian ini bertujuan menguraikan beberapa tantangan yang ternyata timbul ketika orang tua berusaha terlibat dalam proses pembelajaran. Penelitian ini memakai pendekatan kualitatif dengan metode evaluatif. Data diambil melalui kuesioner dan wawancara orang tua dan guru Kelompok Bermain dan TK Gita Kasih I, Gresik, Jawa Timur, Indonesia. Hasil penelitian ini menunjukkan dua masalah utama, yakni: 1) rendahnya sumberdaya berupa latar belakang pendidikan dan pembekalan pelatihan secara profesional; dan 2) kesiapan anak mengenyam pendidikan di sekolah.
\end{abstract}

Kata Kunci: keterlibatan orangtua, inklusi, pendidikan anak usia dini.

\begin{abstract}
Inclusive education in early childhood setting requires collaboration between parents and teachers. This study sought to investigate the challenges which arise when parents make efforts to involve themselves in the learning process. This is a qualitative study with evaluative method. Data were collected by distributing questionnaires and interviewing parents and teachers of Gita Kasih I Preschool and Kindergarten in Gresik, East Java, Indonesia. The result suggests that there are two major areas of challenges, namely: 1) the lack of resources in terms of educational and professional training background; and 2) school readiness.
\end{abstract}

Keywords: parental involvement, inclusion, early childhood education.

\section{INTRODUCTION}

Early childhood education lays the crucial foundation for children with special needs (Ma et al, 2016:772). The governments in many countries have realized the impact of early childhood education in improving children's academic outcomes and life chances (Hedges, et al. 2016:50). Although it is not mandatory in Indonesia, there are various skills which children can learn in this stage. Typically, early childhood education would provide young children with social skills such as sharing, turntaking, and tolerating others. Early childhood education provides early interventions for young children, which would establish social competence and thus ensure positive developmental trajectory if delivered effectively (Garbacz, 2015:151). Early childhood education might also increase language acquisition experiences such as comprehending and completing tasks, as well as listening and 
speaking skills. Those skills are not necessarily academic; however, they contribute to the child's readiness to achieve success in the elementary school.

With the increasing awareness of the importance of early childhood education, the government of the Republic of Indonesia has issued several public laws to support equal opportunity for all citizens to receive proper and appropriate education. The Minister of Women Empowerment and Child Protection of the Republic of Indonesia has issued the Ministerial Regulation which protects the rights of children with special needs, even starting from the gestational period (PPPA no.4, 2017). The government also protects the rights of individuals with disabilities against discrimination, including their basic needs such as education (Laws of the Republic of Indonesia no 8 of 2016). Those public laws strive to ensure the protection of the civil rights and education for the diverse population of children in Indonesia. There needs to be changes in teaching processes, especially in serving the families of young children with special needs in inclusion settings.

In regards to inclusive education services, parents who have children with special needs would likely need to make several adjustments, which might include those of mental and communication. For those families, learning the fact that their child has special needs alone could be daunting (Tait et al, 2016:1164). Larocque et al. (2011) in Owen (2016:8) stated that those parents might encounter terms which can be overwhelming, abstract, scientific, and unfamiliar. Regardless of the socioeconomic status of the parents, teachers still need to make efforts to involve parents in the children's education process and to communicate well with the caregivers (Ankrum, 2016:170). If teachers understand the students' families, according to Podmore et al. (2016) in Hedges et al. (2016:51), they can serve better in terms of developing educational programs which might improve the children's learning, languages, identities, and culture In this case, both parents and teachers need to show more trust, understanding, commitment to communicate, and mutual respect (Steeley and Lukacs, 2015:22).

Parents are the primary educator in a child's life (Mungai, 2015:75). Parents of various ethnic, education, and socio-economic background who are actively involved would contribute significantly to the child's education (Mungai, 2015:76). For example, parents would naturally establish the unique patterns of family communication, disciplinary actions, and routines. A study by Ma et al finds that such patterns are particularly reflected when supervising their children (2016:774). Parents also pass on their faith, beliefs, cultural backgrounds, and values (Sibley and Brabeck, 2017:139; Steeley and Lukacs, 2015:21). Therefore, young children enter the education setting with each individuals' needs. With that in mind, teachers would have to collaborate with the child's parents and other family members in order to serve his/her needs better in terms of school curricula (Ma et al, 2016:775; Caron, Kendall, and Wilson, 2017:451). 
Consequently, considering each child's unique strengths and needs, studies show that he prerequisite for a good partnership between parents and teacher take form in efficient communication (Palts and Harro-Loit, 2015:139). Communication between parents and teachers would give encouragement and empowerment to teachers, and thus make teachers feel that they do not work alone (Dor, 2018:6). In return, parents would gain confidence in knowing that they have made the right decisions regarding their childcare (Coelho, et al., 2018:1). Good rapport may also cause changes in parents' behaviour towards the child's education (Dewi, 2015:119). In fact, Palts and Kalmus (2015:67) conducted a research with the conclusion that active parent-teacher communication would benefit the children because it includes exchange of information about the children's academic and social development.

Parental involvement plays such an important aspect in early childhood education that it would likely affect the achievements. Unfortunately, studies and evidence show that schools do not fully involve parents and provide them with the information regarding their children's learning process and their performance at school (Kraft and Rogers, 2015:49; Gartmeier et al., 2016:207). Parents and teachers may also find some barriers in communication, which bring negative effects (Ozmen, 2016: 29).

Parental involvement and communication may take various media and forms. It may encompass all types of interaction between parents and teachers (Dor, 2018:5). Studies show that school community nowadays take advantage of digital channels such as email, text messages, social network sites, as well as other online platforms (Palts and Kalmus, 2015:65; Palts and Harro-Loit, 2015:139). Epstein (1995) in Owen (2016:3) wrote that school-initiated parental involvement might involve several dimensions, namely: parenting, communicating, volunteering, learning at home, decision making, and collaborating with the community. In this case, parents and schools should establish a mutual agreement as to what level parents might make inquiries regarding their child's school activities, or are involved in the teaching and learning processes.

Despite the important roles described above, parental involvement remains a challenge for early childhood special education (Tait et al, 2016:1164). Forming and maintaining parental involvement needs to be done purposefully and meaningfully. This article aims to study on the challenges of parental involvement in early childhood education, particularly those which provide inclusion for young children with special needs. 


\section{METHODS}

This study uses the evaluative method. Data were collected and analysed systematically to determine the values and worth of an educational practice (Sukmadinata, 2012:120). This method, according to Sukmadinata (2012:120), might enhance knowledge regarding best practices and might encourage further research and development.

The subject of this study is the parents and teachers of Gita Kasih I Preschool and Kindergarten, Gresik. The school provides early childhood education. Among the students, there are children with special needs. Those children are diagnosed with various types of disabilities, i.e.: autism, Attention Deficit/Hyperactivity Disorder (ADHD), and the so-called speech delay. There were 40 parents and 10 teachers involved in this activity.

Data were collected through questionnaires, interviews and discussions with teachers, school staff, and parents. The study was conducted as part of parent-teacher in-service activity in Gita Kasih I Preschool and Kindergarten, Gresik. The in-service was conducted on May 17, 2019.

\section{RESULT AND DISCUSSION}

The inclusive education programs in Indonesia encounter several problems, which might affect the learning processes of students with special needs. The first problem is the human resource. Lack of educational background and professional training in special education, the limited access to reliable source of information, and language barriers remain to be barriers in parental involvement in early childhood inclusive education. The second problem is school readiness. Most early education formal education take place in public facilities, such as the local halls or religious buildings such as mosques and churches. All of the problems abovementioned might contribute to parental involvement in early childhood inclusive education processes.

\section{Parental Involvement}

Beecher, C., \& Buzhardt, J. (2016:50-51) conducted a study which shows how critical parental involvement is to early childhood inclusion. Stage, Wilkerson, Hegde, Lisson, Babatunde, \& Goodell, (2018:161) report the importance of parental involvement in the success of the child's academic processes. When young children feel secure about their environment, including the people who take care of them, they would establish a firm basis of exploration in learning. Thus, they would likely thrive in school environment as well Yoleri, S. (2017:211).

Bang (2018: 1788) writes that teachers of early childhood education realize the importance of parental involvement in the children's development of self-confidence and adjustment to kindergarten. It also benefits the parents' and teachers' attentiveness of the students. Bang (2018:1788) reports that learning opportunities for students can be made available when teachers and 
parents "share information and opinions about the students' experience, cultures, and ways of learning."

Bang (2018: 1789) warns the teachers against mislabelling some parents as “difficult.” Instead of focusing on the parents' unwanted behaviours, teachers should make attempts to be more understanding of the parents' point of view. Beecher, C., \& Buzhardt, J. (2016:51) report that lack of teachers' preparation remains to be one of the most significant barriers in early childhood inclusion. Daniel (2016:7) emphasizes the importance of teachers' attempts to reach out to parents to ensure that those parents are actively involved in the young child's educational processes.

\section{Human Resources}

As mentioned in the previous section, this article aims to study on the role of parental involvement in early childhood education, particularly those which provide inclusion for young children with special needs. In this case, this section is aimed to discuss the interpretation of the writer's findings.

The study involves 40 parents and 10 teachers in Gita Kasih I Preschool and Kindergarten, Gresik. They attended an in-service parenting education program, hosted by the school. Pre-tests and post-tests were distributed and filled out by the end of the program.

The study shows that there are $37 \%$ parents who claim to have adequate background understanding in autism. Due to the limitations to access to information regarding autism in such a small town, parents educate themselves by learning through the internet. A few of those parents attend workshops and seminars about autism. The rest, 53\% of the parents, claim that they have no any understanding about autism. The chart below describes the division:

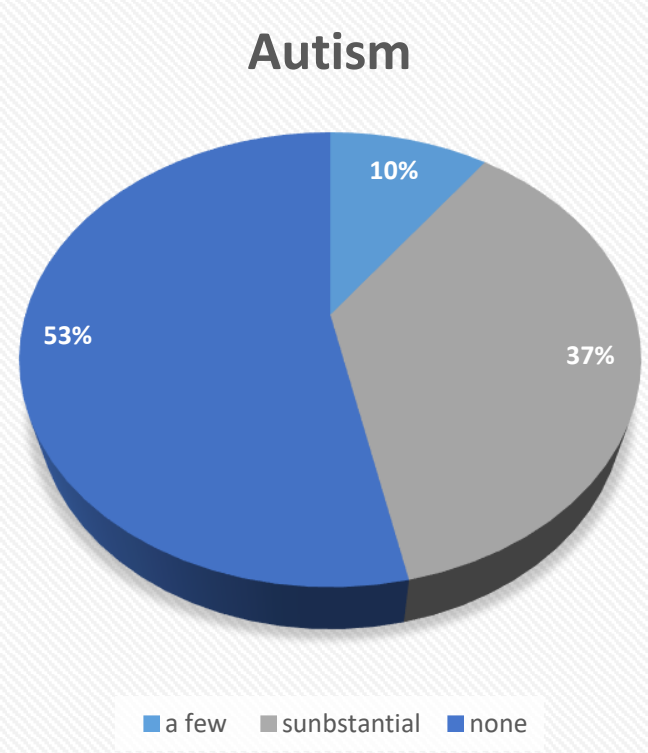

Chart 1. Parents' Basic Knowledge of Autism 
The study also shows that there are $23 \%$ parents who think they have adequate understanding about ADHD. They claim to have limited to some knowledge about ADHD. There are $67 \%$ of the parents who do not understand about ADHD. The chart below describes the division:

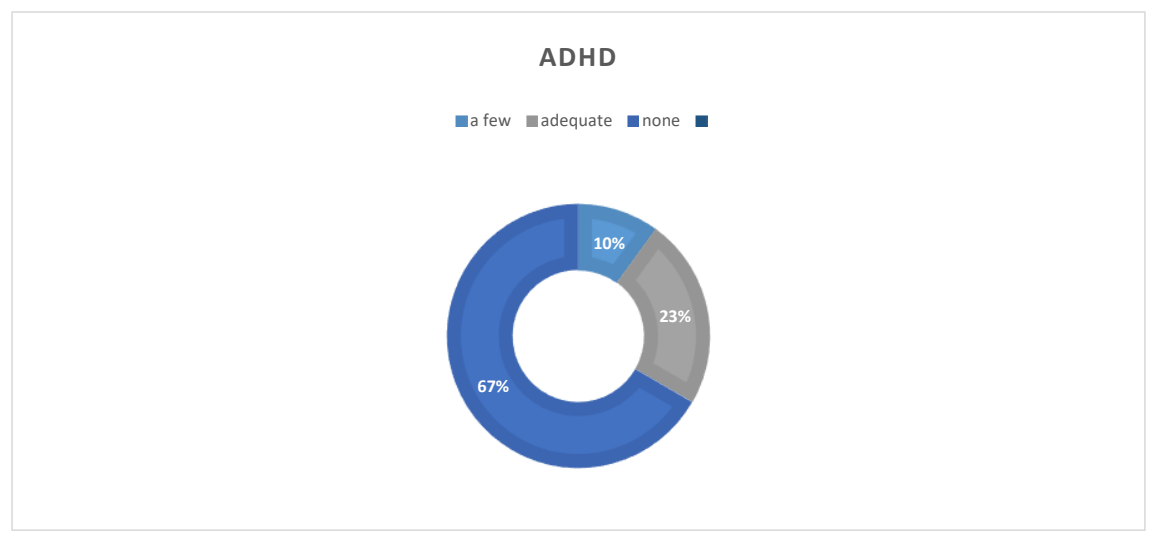

Chart 2. Parents' Basic Knowledge of ADHD

The study reveals that $45 \%$ of the parents claim that they have adequate knowledge about speech delay. As for $41 \%$ of the parents, speech delay is something new. The chart below describes the division:

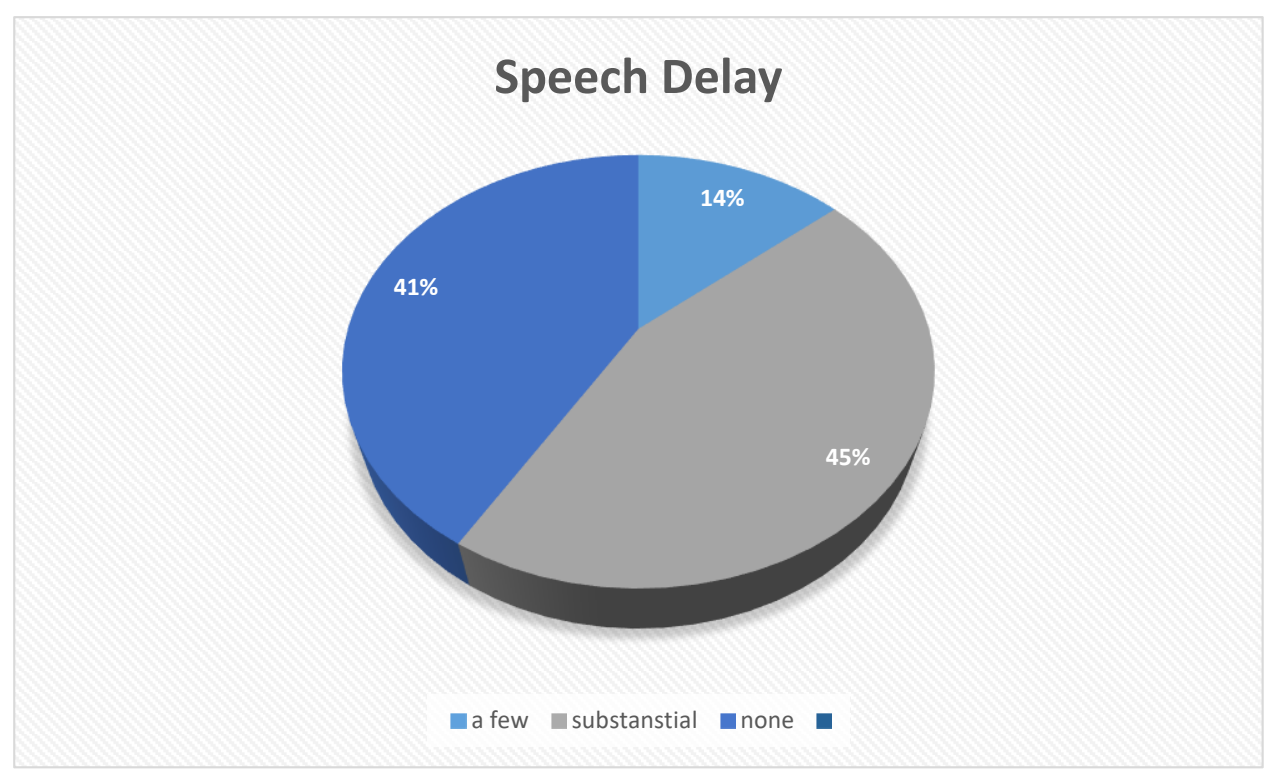

Chart 3. Parents' Basic Knowledge of Speech Delay

A study by Daniel (2016:8-9) shows teaching experience of the teachers also plays an important role in ensuring inclusion process in early childhood education. The diverse needs of the young children with special needs need to be comprehended by the teachers. When teachers have acquired educational background and professional training in inclusion, they are likely to convey the child's progress more tactfully and empathetically. 


\section{School Readiness}

The US Department of Health and Education (2016:2) made a statement that families that are actively involved in their children education right from the start would ensure the success in the child's early education and programs. Ali et al. (2017) reveals that among low-income Hispanic parents, school readiness is even more important than academic and social skills. If a child is wellnurtured, he or she would feel secure and gain more self-confidence. Moreover, families that communicate well and support early education programs would also boost the child's early literacy skills. Thus, the young child would show higher indicators of school readiness.

Nitecki, E. (2015:196) reports the significance of preschool education, which provides a bridge between home and formal education system. In this case, parents play an important role in becoming the first essential system and source of support for the young child's learning process and achievements. Pears, Healey, Yoerger, \& Fisher (2015:3) report the importance of smooth transition between home and school systems. When parents are open to the child's strengths and needs, the school staff could establish a baseline and then develop plans for the young child's education. McLeod, Sharynne et al. (2018:3) write that the sooner a young child's gets an early identification, the sooner early intervention might take place. When parents are actively involved in the educational process, there would be long-term positive academic outcomes for the young children. In addition, the young children would adjust to school system in a more positive way (Pears, et al, 2015:4).

The student intake process at Gita Kasih I Preschool and Kindergarten, Gresik, uses standard procedures. They do not have the appropriate screening tools which detects any early sign of disabilities. Right from the beginning, the staff use their intuition to determine whether they can serve the young children in their school. When they deem that the disabilities are too severe, they decide to refer those children to special education school.

The school staff do not have any formal education about children with special needs. In fact, inclusion should provide each student with the opportunities to develop their strengths and address their needs. The lack of formal knowledge might hinder the teachers to communicate with the parents appropriately and properly.

Due to shortage of information, teachers have difficulties encouraging young children to conduct activities in groups, or bridging the gap between the students' unique strengths and needs. Studies by Al Jaddou (2018:485) has shown that inclusive education practices which work well would bring positive results in terms of attitude and acceptance towards individuals with special needs. Typically developed students who have friends with special needs would show that they are willing to establish friendship, gain useful information, and have positive attitudes towards their schoolmates who have disabilities. 


\section{CONCLUSION}

\section{Summary}

Inclusion is a perennial and altogether delicate matter. When the stakeholders execute each step appropriately, it could be the answer of the young child's needs. On the other hand, inclusion which does not follow the appropriate protocols would only cause more problems, both for the young child's as well as the environment.

Parental involvement plays a significant role in the young child's learning process. When parents are open to new suggestions and continuously educate themselves, inclusion would likely to happen smoothly. However, when parents are ignorant, they would have problems absorbing information, let alone reinforce the child's essential education at home.

School readiness also affects parental involvement in the inclusion education process. The school staff should be well-educated would likely to collaborate with parents well. Those school staff would understand better the young child's strengths and needs, then articulate the message well to the parents.

\section{Recommendations}

Further studies on inclusion in early childhood education need to be conducted. Inclusion requires collaboration among all stakeholders. Educators, therapists, and parents should establish an Individualized Educational Program (IEP) to ensure that the young child's strengths are acknowledged, and his or her needs are met. The IEP would also hold each party accountable. That way, the inclusion process in early childhood education would take place appropriately.

\section{REFERENCES}

Al Jaddou, E. A. 2018. The World Islamic Sciences and Education University Students' Attitudes towards the Inclusion of Handicapped Students within Campus Main Stream. Educational Research and Reviews, 13(12). doi:10.5897/ERR2018.3522.

Ali, Z. S., Coba-Rodriguez, S., \& Jarrett, R. L. (2017). "I write my letters at school, so I'm ready right?” Low-income Latino children's transition from preschool to kindergarten.

Ankrum, R. J. 2016. Socioeconomic Status and Its Effect on Teacher/Parental Communication in Schools. Journal of Education and Learning, 5(1). doi:10.5539/jel.v5n1p167.

Bang, Y. 2018. Parents' Perspectives on How Their Behaviors Impede Parent-Teacher Collaboration. Social Behavior and Personality 46(11). doi:10.2224/sbp.7270 .

Beecher, C., \& Buzhardt, J. (2016). Mobile technology to increase parent engagement. IxD\&A, 28, 49-68. 
Caron, B., Kendall, R., \& Wilson, G. (2017). Taking on the Challenge: Building a Strong Foundation for Early Learning. Early Learning Challenge Summary Report. Early Learning Challenge Technical Assistance.

Coelho, V., et al. 2018. Predictors of Parent-Teacher Communication During Infant Transition to Childcare in Portugal. Early Child Development and Care. February 2018. doi:10.1080/03004430.2018.1439940.

Daniel, G. R. (2016). Parents' experiences of teacher outreach in the early years of schooling. Asia Pacific Journal of Education, 36(4), 559-569.

Dewi, N. F.K., et al. 2015. Early Childhood Behavior Changing in Terms of Communication between Parents and Teachers. Journal of Education and Practice, 6(27).

Dor, A. 2018. Parent-teacher Communication: The Case of Diverse Family Patterns. Education and Society, 36(1). doi:10.7459/es/36.1.02.

Garbacz, S. A., et al. 2015. Congruence in Parent-Teacher Communication: Implications for the Efficacy of CBC for Students with Behavioral Concerns. School Psychology Review, 44(2).

---, et al. 2016. Family Involvement and Parent-Teacher Relationships for Students with Autism Spectrum Disorders. School Psychology Quarterly, 31(4). doi:10.1037/spq0000157.

Gartmeier, M., et al. 2016. How Do Teachers Evaluate Their Parent Communication Competence? Latent Profiles and Relationships to Workplace Behaviors. Teaching and Teacher Education, 55. doi:10.1016/j.tate.2016.01.009.0742-051X.

Hedges, H., et al. 2016. Aspiring to Quality Teacher-Parent Partnerships in Vietnam: Building Localised Funds of Knowledge. International Research in Early Childhood Education, 7(3).

Kraft, M. A., and Rogers, T.. 2015. The Underutilized Potential of Teacher-to-Parent Communication: Evidence from a Field Experiment. Economics of Education Review, 47. doi:10.1016/j.econedurev.2015.04.001 0272-7757.

Ma, X., Shen, J., Krenn, H. Y., Hu, S., \& Yuan, J. (2016). A meta-analysis of the relationship between learning outcomes and parental involvement during early childhood education and early elementary education. Educational Psychology Review, 28(4), 771-801.

McLeod, S. et al. 2018. Preschool children's communication, motor and social development: Parents' and educators' concerns. International journal of speech-language pathology, 20(4).

Mungai, D. N. (2015). Relative Contribution of Different Levels of Parental Involvement to Primary School Readiness in Preschool Pupils in Nairobi County. Journal of Education and Practice, 6(29), 74-80.

Nitecki, E. (2015). Integrated School-Family Partnerships in Preschool: Building Quality Involvement through Multidimensional Relationships. School Community Journal, 25(2), 195-219. 
Owen, A. N. 2016. Forming Collaborative Parent-Teacher Relationships to Increase Parental Involvement. Independent Studies and Capstones. Paper 728. Program in Audiology and Communication Sciences, Washington University School of Medicine.

Ozmen, F., et al. 2016. The Communication Barriers between Teachers and Parents in Primary Schools. Eurasian Journal of Educational Research, 66. doi:10.14689/ejer.2016.66.2.

Palts, K., and Harro-Loit, H. 2015. Parent-Teacher Communication Patterns Concerning Activity and Positive-Negative Attitudes. TRAMES, 2015, 19(69/64). doi:10.3176/tr.2015.2.03

---, and Kalmus, V. 2015. Digital Channels in Teacher-Parent Communication: The Case of Estonia. International Journal of Education and Development using Information and Communication Technology 11(3).

Policy Statement On Family Engagement: From The Early Years to The Early Grades. 2016. U.S. Department of Health and Human Services \& U.S. Department of Education. May 5, 2016.

Pears, K. C., Kim, H. K., Healey, C. V., Yoerger, K., \& Fisher, P. A. (2015). Improving child selfregulation and parenting in families of pre-kindergarten children with developmental disabilities and behavioral difficulties. Prevention Science, 16, 222-232. doi:10.1007/s11121014-0482-2.

Sibley, E., \& Brabeck, K. (2017). Latino Immigrant Students' School Experiences in the United States: The Importance of Family-School-Community Collaborations. School Community Journal, 27(1), 137-157.

Stage, V. C., Wilkerson, K., Hegde, A., Lisson, S., Babatunde, O. T., \& Goodell, L. S. (2018). Head Start administrator and teacher perceptions of parental influence on preschool children's nutrition education. Journal of Early Childhood Research, 16(2), 160-175.

Steeley, S. L., \& Lukacs, K. (2015). Cultural and Linguistic Diversity and Special Education: A Case Study of One Mother's Experiences. International Journal of Special Education, 30(2), 20-31.

Tait, K., Fung, F., Hu, A., Sweller, N., \& Wang, W. (2016). Understanding Hong Kong Chinese families' experiences of an autism/ASD diagnosis. Journal of Autism and Developmental Disorders, 46(4), 1164-1183. 